\title{
Unconscious aspects of sustainability in modern and postmodern religious architecture in Poland
}

\author{
Joanna Gil-Mastalerczyk ${ }^{1, a}$ \\ ${ }^{1}$ Kielce University of Technology, Faculty of Civil Engineering and Architecture, Al. Tysiąclecia Państwa Polskiego 7 , 25-314 Kielce, Poland
}

\begin{abstract}
The emergence in recent decades of the idea of sustainability and sustainable development significantly affected the innovative approach to architectural design and urban planning. The article presents contemporary examples of the Polish works of sacred architecture and urban planning, which prove the unconscious use and incorporation of the concept of the architectural values of the environment, including climate, solar energy and other natural elements such as landform, structure or green water. The analysis of the contemporary examples of architecture, realized in the second half of the twentieth century, confirms that such actions are taken. The search for a friendly urban space combines the comfort of living with the comfort of the natural environment. The contemporary objects and sacral complexes testify to integrated planning with nature. The system of architectural and urban planning objectives is clearly reflected in the functioning of thecity and how to organize the use of space, including an attempt to rebuild a sustainable relationship between the infrastructure and the natural environment. When designing the contemporary forms, sacred has become very important in addition to the historical past, the identity of individual urban structures, at the same time, maintaining the high quality of the environment. Projecting of harmony with the local climate and the use of natural conditions in urban planning.
\end{abstract}

\section{Introduction}

The contemporary architecture and urban planning impose environmental measures. Sustainable architecture has three main areas of conditions: environmental, social and economic. The Ecological Urbanism introduces principles of ecology to the urban planning and emphasise the social inclusion and sensitize to the environment. On the other hand the idea of design in the vein of ecological urban planning is based on the interaction of the human measures and natural processes of the city (air, earth, water and life, ecosystems), ie. the adjustment of the city to the natural processes [1].

Harmonious relationships between created environment and the nature, tender different scales and forms, serve to human comfort as well as settle the unique quality of each architectural style and urban composition. Mentioned relationships enrich the urban space with a new values, improving its health and aesthetic benefits as well as its attractiveness [2].

In the context of implementing the concept of sustainability and sustainable development, the intensity of the integration between the urban fabric and the environment may be one of the most important criteria for assessing the quality of the contemporary urban space.

Relationships between the architecture and the nature can be seen in various aspects and scales. The rating depends on the integration of the architectural and urban planning plank with the environment and the landscape. It also depends on analysis of the undertaken actions on a small scale, such as the inclusion of various forms of nature in the architectural development [2].

The arrival of the idea of sustainability and sustainable development in recent decades significantly affected the innovative approach to architectural design and urban planning. These ideas have an impact on the new view into the modern city forming.

The achievements in the field of applied technology in terms of its compliance with the natural environment have been changed.

This article presents examples of creating harmonious relations linking the created environment with the nature. It also raise a question of selected issues related to sustainable architectural and urban planning sacral ensemble designed - in Malopolska (Poland).

The unity of architecture and environment maintaining a balance between architecture and natural ambient or shaped by a human - has an positive impact on the quality of the surrounding environment. Relations with the surrounding architecture are defined by the functional, spatial and esthetic interassociations. functional, spatial and aesthetic.

It's regarding the relationship between architectural form and the shaping of the ambient space [3].

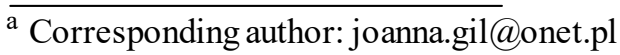




\section{The aspect of sustainability and sustainable development in the urban planning shaping - exampled on modern sacral architecture}

In 1987, in the report "Our Common Future" (known as the Brundtland) prepared by the World Commission on Environment and Development (UN) the concept of sustainable development was defined It was found that the rules of sustainable development should be implemented by all countries. Only then it will be possible to meet the needs of present and future generations [4].

Sustainable architecture is one that is realized in accordance with the principles of sustainable development. The strategy of sustainable development encompasses three dimensions - environmental protection (ecology), social inclusion and economic growth as well as seven key challenges in the area of economic, ecological and social:

- Limiting climate change and promoting clean energy,

- Ensuring that transport systems meet the requirements of environmental protection,

- Promoting sustainable patterns of production and consumption,

- better management and prevention of excessive exploitation of natural resources,

- promoting high-quality public health,

- creation of a society based on social inclusion, and ensuring high quality of life,

- active promotion of sustainable development and to ensure the compliance of the EU in this aspect [5].

Analysis of examples modern and post modern Polish sacred architecture (80s and $90 \mathrm{~s}$ of the twentieth century), reveals that the realization of these features (admittedly unconscious) formation sustainable environmental future. The creators of the buildings did not take any attention to achieve integrated governance - social, economic, environmental and spatial planning [6]. However, contemporary religious assumptions (implemented in Poland in the second half of the twentieth century), testify to the use of urban values of the environment and integrate into the architectural and urban planning concept. There are various forms of wildlife, such as climate, solar energy and other natural elements like topography, the structure of greenery and water which are betaken.

Sacral architecture has become one of the most recognizable elements of the landscape of Southern Poland (Region of Małopolska). Natural lay of the land aids the exposal of number of the modern realizations, which have predominant architectural features of the local, artistic and cultural importance.

In the process of architectural and urban planning design the landscape becomes an important part of the context. The urban context loom large. It eventuates from elicitation" the place identity" and "it is an element of inspiration for creative investment" [3]. Instead of that, building's forms often have the regional connotations.

Contemporary sacral assumptions are featured by the attempt to rebuilt the sustainable relationship between built and natural environment. Areas of specific cultural and natural values (due to geological, geographical and historical conditions) can have a significant impact on the contemporary forms and spatial layout creation of groups and single sacral objects.

\subsection{Sanctuary of St. Joseph the Guardian of Family in Kielce (Sanktuarium Świętego Józefa Opiekuna Rodziny) - complement of the urban and public space, public-oriented, combining recreational and cult functions}

The post-conciliar form of Sanctuary of St. Joseph the Guardian of Family in Kielce (1975-1995, designer W. Pieńkowski), in plan, refers to the rich geological past of the region of Kielce. The fifth elevation of monumental solid of the church recales its shape imprinted shell in the rock. The monumental concrete solid of the church dominate in a special way in the natural landscape of the city and is a clear sign of this place (Fig. 1).

The Sanctuary constitute the important place in the city. It is surrounded by housing and leafy territory it provides quietude, safety and proper coexistence between nature and urban structures to the public.

Native limestone sourced from the quarries of Kielce Region played the key role in the way of shaping the solid of the Sanctuarya. Sourcing a limestone is associated with centuries-old history of the exploitation of primary commodities of the rocks. They are offering stone coming from different geological ages extracted from still active mines.

The use of the Pińczów limestone deposits can be observed in the outside architecture of the temple - as a building material and also used for making stone details (Fig. 2-3).

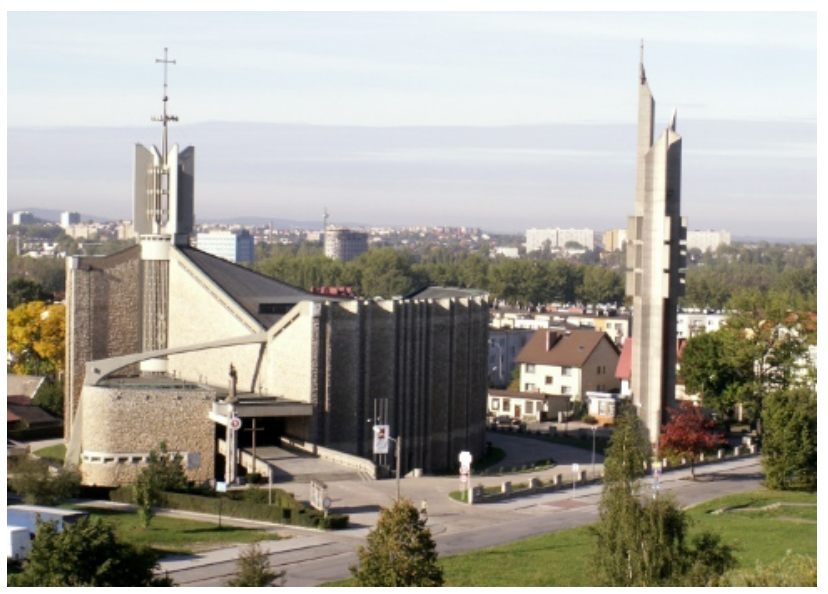

Figure 1. The Sanctuary of St. Joseph the Guardian of Family in Kielce, general view of the sacral solid (photo by J.GilMastalerczyk, 2014).

The whole mold is topped with a roof, with the slope referring to the neighboring hills.

The natural surroundings of the church, including the local conditions - a significant difference in levels, a huge number of leafy territory has influenced on the final shape of the building. They had an effect on the

\footnotetext{
a The Quarry - area Chęcin, Słopca, Sukowa, Tumlin, Pińczów [7].
} 
functional and spatial arrangement of routes. Several entrances using the natural environment and the different decline lead to split-level interior (Fig. 2).

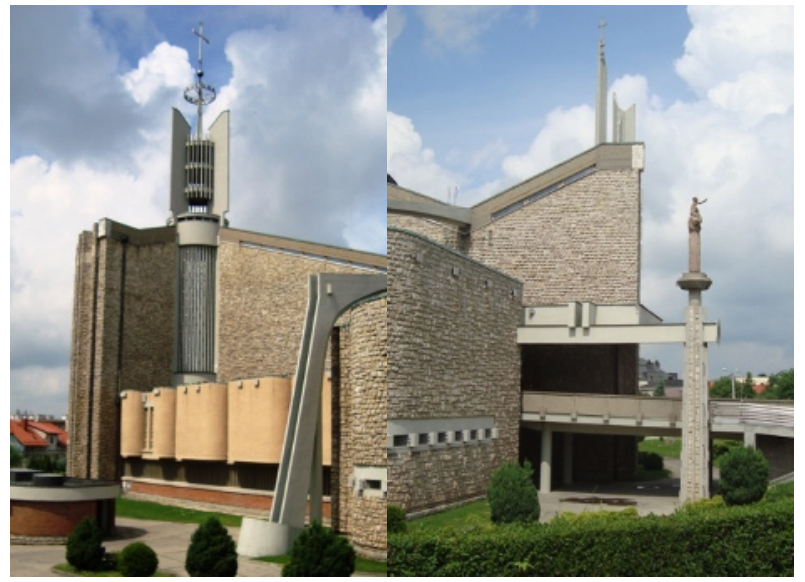

Figure 2. Sanctuary of St. Joseph the Guardian of Family in Kielce, views of solid, blocks, sequence of paths (photo by J.Gil-Mastalerczyk, 2014).

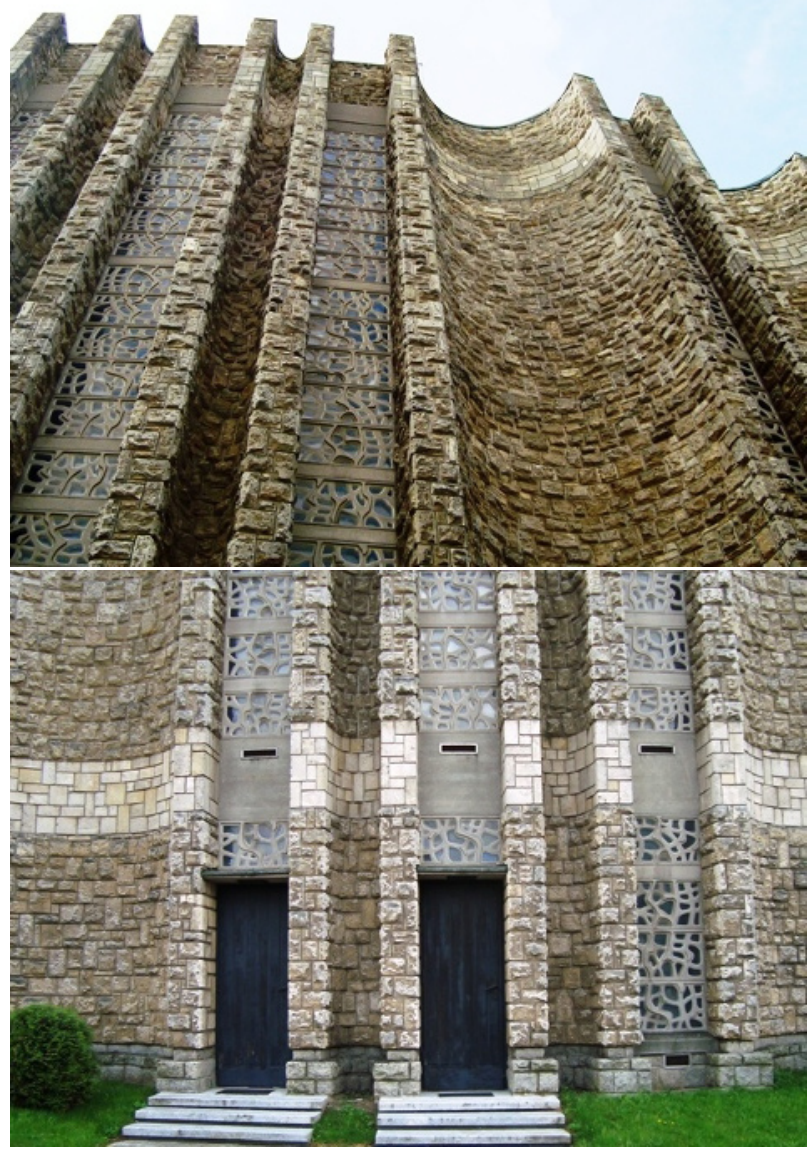

Figure 3. Sanctuary of St. Joseph the Guardian of Family in Kielce, the architecture of the exterior walls - Pińczów limestone of stones` detail (photo by J.Gil-Mastalerczyk, 2014).

The facades of the church designed in the form of undulating walls are inspired by the natural lay of the land. Also the interior organization of the temple, just as the architecture of sacral group of buildings, clearly refers to the character of the natural landscape. The advantages of natural environment are used by the spatial organization and the architectural detail. The glazing windows - in the shape of colored stained-glass windows with its composition and divisions, recall the branches of trees filtering to the interior of the solid the colorful light. The external light falling down through the huge glazing is creating the metaphorical air of the inside.

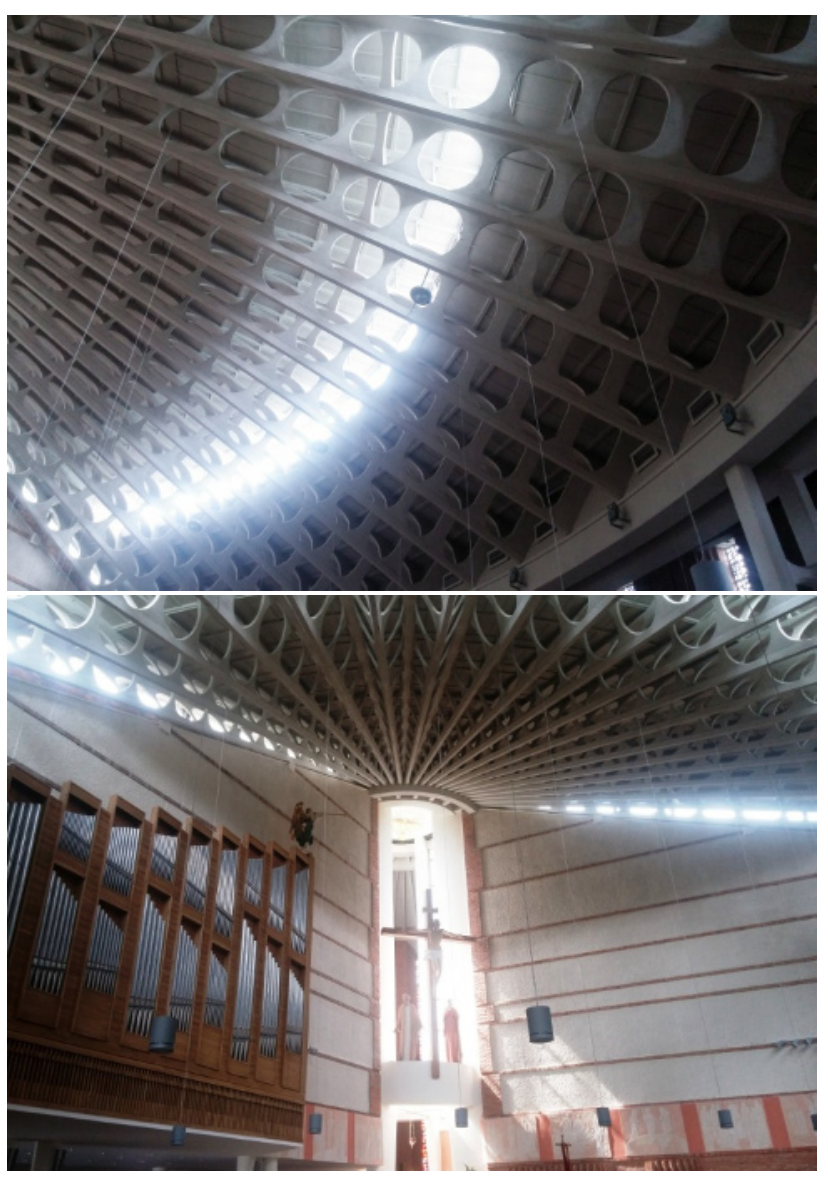

Figure 4. Sanctuary of St. Joseph the Guardian of Family in Kielce, view of the interior - natural light coming from the top to the inside of the temple (photo by J.Gil-Mastalerczyk, 2014).

The natural light has become a factor in shaping the image and specific mood of the object (Fig. 4).

The use of large glazing has a beneficial effect on the level of natural lighting and the aspect of saving energy. Glazing used in external walls play an important role in the development of energy-efficient architecture. Appropriate use of glass also affects the improvement of the energy balance of the building.

Interconnection of materials, their texture and color as same as relationship with natural environment has become an important factor in shaping the solid of the church and its perception. Regional materials, advantages of natural environment and landscape context played the key role in shaping the modern form, despite of using reinforced concrete construction.

The use of local stone materials (limestone, granite) with a long shelf life has an economic dimension. The availability of local raw materials - in economic terms - reduces construction costs and provides speedy transport.

The solid was integrated into the natural environment and was bed in relationship with high and low leafy neighborhood (bushes and well-kept lawns). 
Regional materials, used by the creators, are featured by the creative adaptation to contemporary forms while respecting the identity of the place. The architecture of the church is the result of a dialogue of modernity with tradition of the region and the surrounding nature.

It creates a welcoming space for the community.

In summary, the whole founding of the architectural and urban-planning of St. Joseph the Guardian of Family in Kielce is a representative example of contemporary ideas, which are exposing the value of regional traditions. They have a positive influence on the architecture of sacral objects, their dialogue with the environment and the way of functioning in the surrounding area. The authors of the project offered modern architecture which is a continuation of the modernistic tradition and which is harmoniously united with the natural landscape of the region of Kielce.

The building in Kielce represents contemporary Polish sacral architecture with high aesthetic values - for example the way of using advantages of the surrounding landscape. The church is a part of it.

It should be emphasized that features such as integration with the landscape, take into account the cultural context, the design of large green areas, the implementation of the social - characterized by today's investment of balance. The compound creates the composition of the public space attractive in terms of natural surrounding. The building is important for the status, image and urban-planning composition of the city.

In general, it should be noted that the Church has the characteristics of building a sustainable environment. Building creates a safe and healthy environment for the community staying. Rewarding users from staying in it and a pleasure to contact the outside for passing. The architecture of the church reflects the social and cultural aspirations of society. The building does not have a negative impact on environmental pollution (no hazardous waste). In shaping the architecture of the building it becomes visible aspect of the use of solar energy - provided by your desired orientation of rooms and glass partitions in relation to the world.

In the $80 \mathrm{~s}$ and $90 \mathrm{~s}$ of the twentieth century, when the building was designed, did not focused on the problem of energy efficiency. The introduction of renewable energy sources or activities preferring ecological transport.

The solutions reduce water consumption, saving raw materials are not taken into account, innovation and quality of design solutions, at this time (according to the principles of sustainable development).

The creators of the object represented a lot of attention to the integration of the church with the environment and related to the comfort of use. The architecture of the church, particular attention was paid to regional priorities (the use of local materials stone, tradition of building) and the ecological values of the area.

At present, according to the standards, with an emphasis on issues of sustainable development (LEED- Leadership in Energy and Environmental Design, USA; GBC - Green Building Challenge, Europe, Japan, Canada, USA, BREEAM-Building Research
Establishment Environmental Assessment Method, United Kingdom; BEPAC-Building Environmental Performance Assessment Criteria, Canada) the buildings should be considered in the full cycle of operation (life cycle). Important become all stages, such as stage design, implementation, operation building and its utilization [5].

\subsection{The architectonic sacral complex of St. Peter's the Apostle in Wadowice - a harmonious fusion of the cult places with the socio-recreational function and whit the landscape}

The architectonic sacral complex of St. Peter's the Apostle in Wadowice (1986-1991, designer Gyurkovich J., E. Węcławowicz-Gyurkovich, P. Szafer), is an example of organized urban space using the values of the natural landscape, while becoming a part of it. The project is a part of a typical natural conditions of the location, a context of the existing buildings and the context of the existing landscape.

It should be noted that the designers have taken action (though unconscious) for sustainable development at the regional level. At present, sustainable development is presented in relation to three (economy, society, environment) or four (in addition spatial order) dimensions and relationships between them. The elements of the natural environment can be replaced besides the resources (soil, water, vegetation, animals) values of intangible and difficult to quantify, such as landscape or space (relevant and important from the point of view of economics).

The sacral complex has been surrounded by modern housing estates from two sides. From the side of the city is in immediate vicinity of the old cemetery, set on the background of beskid Maly slope's, which is towering above. The amorphous space of "modern" housing state provoke the need to create clearly defined space, referring to the historical traditions of monasters compexes which are separating sacrum and profanum, from the urban principles that form building lines and urban interiors - streets, public squares and parks [8].

The sacral complex of the buildings has an axial composition. The church of St. Peter's the Apostle (on the traditional Latin cross plan, with a longitudinal layout) was located in the center of it and was surrounded by a "wall" of didactic, social and residential buildings, referring with its composition to the complexes of historical monasteries. The "wal sl" line is continuated on the south side by a double row of trees [9] (Fig. 5).

The gate - in the form of a triumphal arch (which has not been done) reffering to the form of western elevation and the dome of the Vatican Basilica - was designed in the axis of the complex [10].

The whole complex also includes the freestanding towering tower, the chapel of Christ the King, the building with rooms to learn (converted to residential ${ }^{\mathrm{b}}$ ) and also situated behind the church and using the natural

${ }^{\mathrm{b}}$ Author's interview with E. Węcławowicz-Gyurkovich, Krakow, 11 March 2013. 
lay of the land - The Way of the Cross, also known as "The Wadowice`s Golgotha"c (Fig. 6).

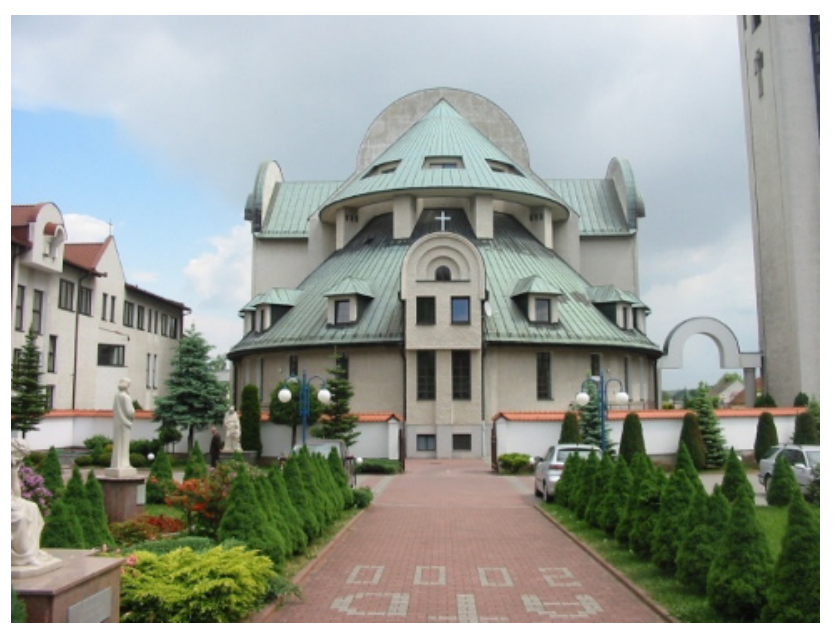

Figure 5. The sacral complex of buildings of St. Peter's the Apostle in Wadowice, the solid view of the church from the green hills (photo by J.Gil-Mastalerczyk, 2013).

The architecture of sloping roofs or small scale of detail are a continuation of the local, regional traditions. The composition of the processional way with symbolic gates refers to the architecture of the old streets of Krakow, and the internal and external colonnade repeat the atmosphere of the Vatican [11] (Fig. 7).

The presented characteristics indicate on application of the principles of sustainable development (respect for the terrain and the landscape context, integration with the landscape, use of local building traditions, the implementation needs of the community and enhancing social cohesion, the use of safe materials, proper orientation of the building, windows and rooms - impact on energy savings).

The organization of the postmodern church's interior uses natural advantages of the environment. The natural light inside the temple has particular importance. It is inextricably linked with the imagery of the sanctuary.

The natural light is an important factor in forming the image of the building - not just architectural image. The effect of natural light plays a key role in creating and reading the interior of the temple. Conscious creation of light, as one of the of the natural environment parameters, brings structure's harmony, underlines the space and perfect form's proportions.

In summary the sacral complex of buildings of St. Peter's the Apostle in Wadowice, is an example of a new architectonic creation, while respecting the quality of traditional architecture and landscape context.

The spatial and architectonic solutions of the sacral complex of St. Peter's the Apostle come from the interpretation of the overall conditions of the location. The compositional structure of the whole architectonic complex set "a strong form" of amorphous space of the surrounding housing estate [8].

\footnotetext{
c The whole sacral complex has a deep symbolic dimension. According to the authors of the project: (...) Processed Wadowice `s, Cracow's, and especially Rome 's architecture quotes, included in this complex are (...) to symbolize the Way of the Great Pole to the Holy See [9].
}

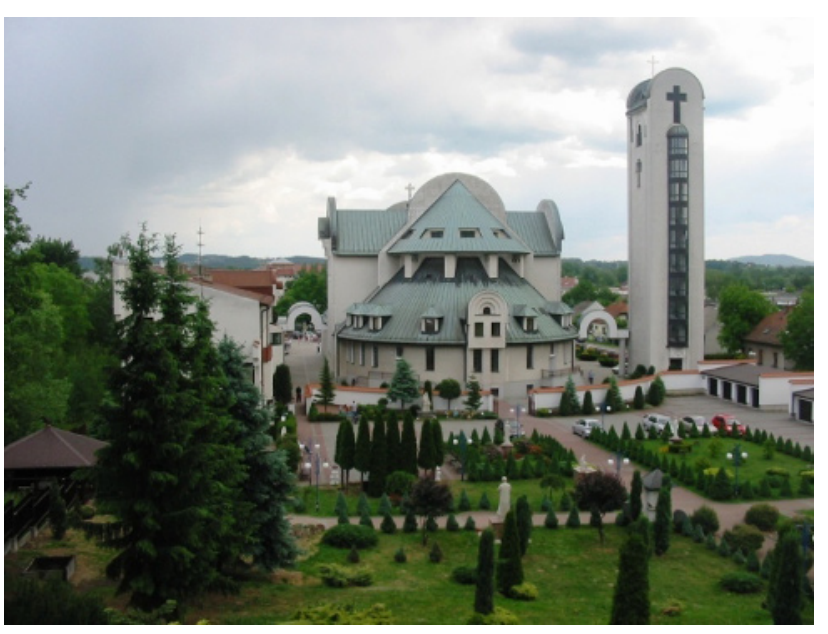

Figure 6. The sacral complex of St. Peter's the Apostle in Wadowice, the view of "Wadowice's Golgotha" (photo by J.Gil-Mastalerczyk, 2013).

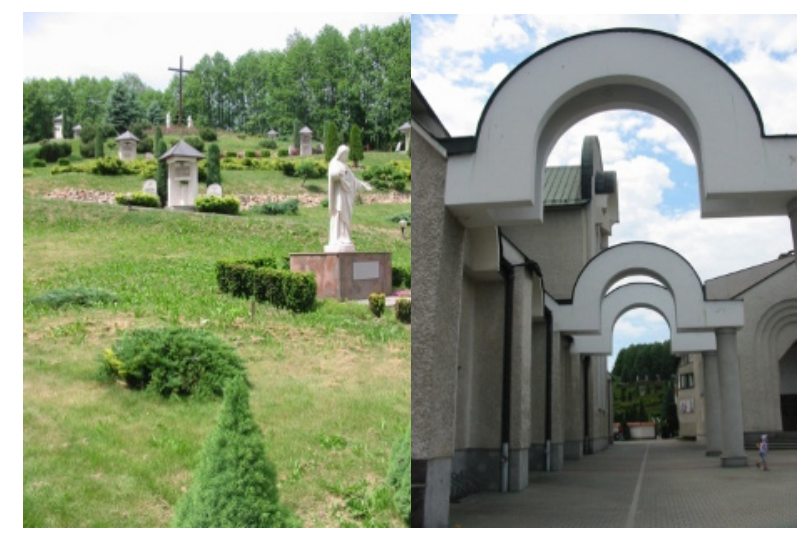

Figure 7. The sacral complex of St. Peter's the Apostle in Wadowice, the walking paths, "processional way" (photo by J.Gil-Mastalerczyk, 2013).

The designers have offered a modern architecture, open to the natural environment and harmonically weld with the landscape [11]. These are important elements in the process of sustainable development. According to A. Baranowski balancing relationship "built environment natural environment" is one of the primary aims of sustainable architectural design [6].

All buildings, located on a meadow close to an old river basin of the Skawa evoke in perception from different sides aesthetic impressions marked with the sacral imagery and the cohesiveness of the composition with surrounding environment [12].

It was uniquely integrated with undulating land blurring the institutional boundary between the sacrum and the profanum. The solid form a contemporary interpretation of processed simple geometric forms creating a distinctive atmosphere in the existing urban fabric and also facilitating finding in the structure of the city an important public space, which combines the social and recreational functions with buildings of religious worship. Owing to that, the complex does double duty as the parochial center, votive places of worship and it provides live comfort and convenient contact with the nature.

The complex has good composition in the ground. The church in a creative way compose a new place of 
symbolic shape subserving to both liturgical and secular purposes.

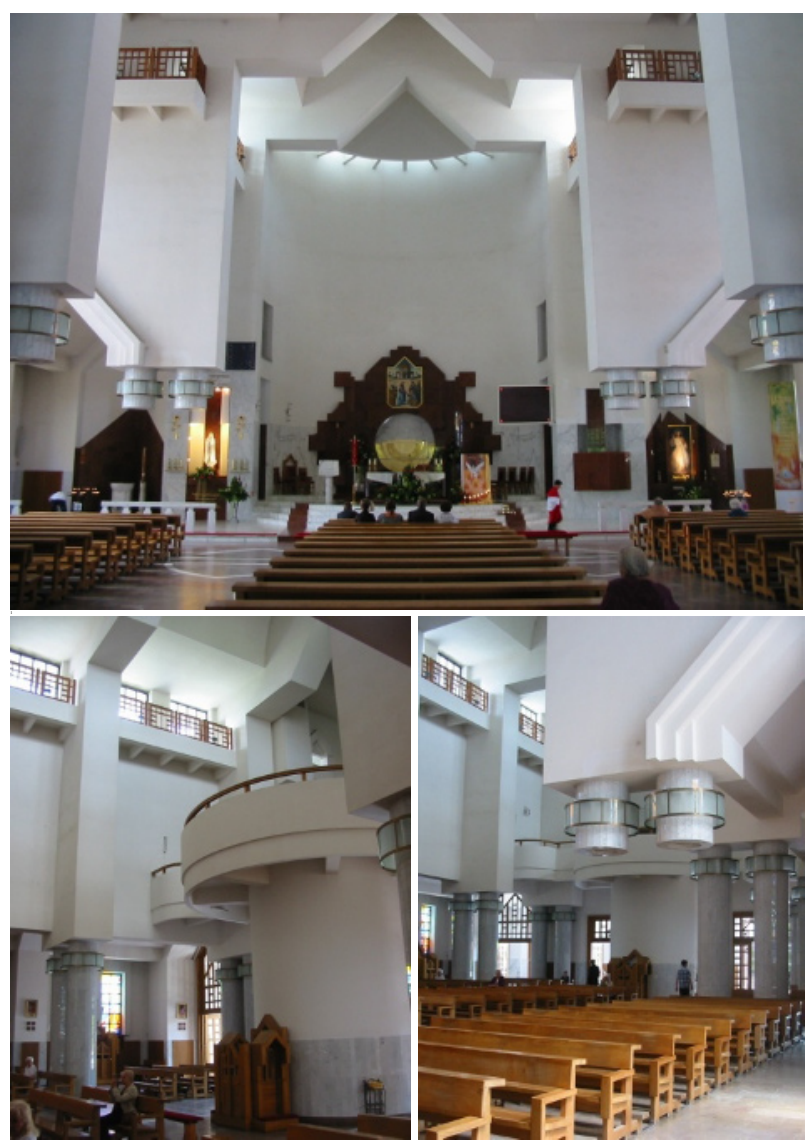

Figure 8. The sacral complex of buildings of St. Peter's the Apostle in Wadowice, the view of the interior (photo by J.GilMastalerczyk, 2013).

The whole complex significantly influenced on changing the layout of visual city elements and has become a modern symbol of the sequence of the city. It is an example of changing the existing architectonic patterns and creating other formal solutions in contemporary sacral architecture. The place fully integrated with the natural terrain has been created to provide users ' comfort with the comfort of the natural environment. The sacral buildings have become a part of the space in which they exist. Through its construction material and its size they dialogue with the surrounding streets and buildings. A wide context of the environment, landscape and larger fragments of the nature are part of the construction project.

In conclusion it should be noted that the assumption sacred in Wadowice was formed, taking into account (though unconscious) sustainable three fundamental aspects of development: social, environmental and economic.

Social aspect: extensive social participation - in the process of use; increasing social cohesion through the implementation of social space, new public spaces (character sacred and secular) have the ability to produce human coexistence - in a diverse open space and architecture; formation new meeting space - with different activities; development of safe, open structure of the city through a smooth transition between public space and private, attractive external program stimulates a rich social life; the use of safe materials (respect for the user).

Ecological aspect: the introduction of diverse habitats in the landscape of the city - development of various forms and green areas allow to exist rich flora and fauna in the city center; integration with the landscape and taking into account the cultural context; increase the area of biologically active; in the area of the new structure is planned pedestrian and bicycle traffic (environmentally friendly); building structure with traditional materials (non-toxic);

Economic aspect: the introduction of functional diversity and spatial; Buildings (secular-residential, educational, religious) and recreational areas were built with the aim of perspective functioning; use of materials and technical solutions with a long durability period.

Unfortunately, it is does not apply to new methods and effects, which should be of high quality technical solutions. The lack of new technologies 3Rs (reduce, reuse, recycle), energy savings and use of alternative energy sources and minimizing pollution.

\section{Conclusions}

In the present time (in the threat environment and economic crises) the role of architecture and construction in the creation of sustainable development is very important. Architecture and construction represent largest sector of the economy in the economic aspect and in terms of the flow of raw materials. In building invested the largest amount of financial capital and mineral resources was invested. One of the main aim in the construction industry becomes improve the quality of life, which should be permanent in nature, should involve current and future generations and should not cause degradation of the natural environment. In contrast, the activity aimed to meet the needs should take into account environmental protection as a condition for proper management.

According to the so called new economy environmentally sustainable development aims to ensure that all people living today and future generations sufficiently high standards of environmental, economic and socio-cultural limits of the natural strength of the Earth, applying the principle of intra-generational and intergenerational justice [13].

It should be emphasized that the concept of sustainable development is assumed to maintain a balance between the general dimensions (social, economic, environmental). None of them should be treated as a parent. However, in practice, it seems difficult to obtain.

Professor G. Sznajder-Skalska claims that among scientists and practitioners (in the field of architecture and urban planning) there is a consensus as to the general features characterizing investments balanced. These are investments in which the following principles.

- Respect for the area (taking into account the cultural context, the use of local materials and traditional building (...), integration with the landscape, increasing the area of biologically active (...)), 
- Respect for the user (realization of the needs of each individual, high quality architecture and space $(. .)$.$) ,$

- Reduce, reuse and recycling (Rule 3 r), covering a group of actions that result should be saving and re-use of area, the volume and materials (...),

- Energy efficiency (use of efficient insulation, proper orientation of the building and facilities, minimizing heat loss and passive solar energy gain $(. .)$.$) ,$

- The use of alternative energy sources (use of highquality technical solutions in order to obtain solar, wind, geothermal sources (...)) [14].

In the presented examples (Wadowice, Kielce) many of features of sustainable investment may be foud. Although adopted (unconsciously) solutions in the $80 \mathrm{~s}$ and 90 s were not seen in terms of design and sustainable development.

The arrival of the idea of sustainability and sustainable development in recent decades significantly affected on the innovative approach to architectonic design and urban planning. The analyzed examples characterized by spatial and ecological variety of solutions, as well as a harmonious relationship with the landscape and the immediate surroundings.

They are distinguished by the high quality of architecture and the systems of composition, friendly attitude towards the private and the public space, a strong relationship with the nature. It creates all together integrated totality - harmoniously integrated architecture in environment creating a harmonious relationship with nature and built-on area.

Diverse and complementing functions harmoniously coexisting in the urban structure provide environmentally sustainable development of urban area. Opening the architecture on the natural environment combines activities in the economy, ecology and society. (...) It implements the ideas of forming the economical city, among others through cost-effective management of the terrain and resources of existing buildings (...), and natural resources: water, raw materials, materials (...) [15].

The expressive continuation of the landscape and traditional sacral architecture of region Malopolska is presented in buildings ' architecture. The landscape context and confrontation with the environment of analyzed buildings had a significant impact on making the constructions' decisions by the designers. The architectural forms have been harmoniously integrated into the natural landscape at the same time not exerting a strong contrast on the present buildings.

The architectonic approaches stem from the landscape`s features, especially its scale. They were developed as a result of creative transformation process and interpretation of the local forms.

In the contemporary solutions regional elements of architecture, such as a silhouette, slope roofs regard to the climate conditions - were used.

In summary, all presented contemporary buildings and sacral complexes attest about an integrated planning with the nature. The system of architectonic and urban planning projects clearly reflected in the way of functioning of the city and in the way of organizing and using the space, including an attempt to rebuild a sustainable relationship between built environment with the natural environment.

The concurrent maintaining of a high quality of natural environment instead of the past and particular urban structures' identity has became very important in designing contemporary sacral forms. Design stays in harmony with the local climate and the use of natural conditions in urban planning.

It should be noticed that the presented buildings of contemporary sacral architecture attest the high sensitivity of the designers on the context. The shaping environment related to religious building, is to be performed with respect for public space natural and cultural landscape with the use of contemporary solutions, functional and spatial, technological, and material creates the optimal conditions for the society. The analysis of contemporary examples of architecture, done in the second half of the twentieth century, confirms that such actions are taken. They express a guest for a friendly urban space, which combines the comfort of living with the comfort of the natural environment. The buildings are created in harmony with the natural environment and respect the conditions of the environment. This applies to relationships of coming into being buildings in the urban fabric with both the natural landscape and the urban space, at which a new quality of the architectonic and urban planning and architecture being in line with the modern times.

\section{References}

1. A. Spirn, Ecological Urbanism: A Farmework for the Design of Resilient Cities (2012).

2. S. Wehle-Strzelecka, Współczesne miaston jako środowisko zycia człowieka zintegrowane $z$ przyroda/ The modern city as a human environment integrated with nature, Architektura 2/2015, Wyd. Politechnika Świętokrzyska w Kielcach, 5 (Kielce, 2015).

3. W. Seruga, Jedność architektury z otoczeniem/ The Unity of Architecture and its Surroundings, Czasopismo Techniczne Architektura/ Technical transactions Architecture, 3-A/2011, Z. 12, rok 108, Issue 12, Year 107, p. 133-145 (Wyd. Politechnika Krakowska, Kraków, 2011).

4. World Commission on Environment and Development. Our cammon future, the rapport of the World Commission on Environment and Development, (Oxford University Press, New York, 1987).

5. L. Kamionka, Standardy architektury zrównoważonej jako istotny czynnik miasta oszczędnego na przykładzie wybranych programów certyfikacyjnych [w:] Czasopismo Techniczne Architektura/ Technical Transactions Architecture, Issue 14, 6-A /2010 Year 107, p. 27-38 (Wyd. Politechnika Krakowska, Kraków, 2010).

6. A. Baranowski, Projektowanie zrównoważone w architekturze, p. 44, 89 (Wyd. Politechnika Gdańska, Gdańsk 1998). 
7. J. Jędrychowski, Kieleckie kamienie $w$ architekturze [w:] Renowacje i zabytki, No. 4 (52), p. 34-40 (2014).

8. J. Gyurkovich, Znaczenieform charakterystycznych dla ksztaltowania i percepcji przestrzeni, Wybrane zagadnienia kompozycji $w$ architekturze $i$ urbanistyce, Seria Architektura, Monografia 258, p. 109-110 (Wyd. Politechnika Krakowska, Kraków, 1999).

9. E. Węcławowicz-Gyurkovich, Współczesna polska architektura sakralna $w$ twórczości krakowskich architektów. Wybrane zagadnienia, [w:] Kwartalnik Architektury i Urbanistyki, tom XLI, zeszyt 3-4, Polska Akademia Nauk Komitet Architektury i Urbanistyki, p. 327 (Wyd. Naukowe PWN, Warszawa, 1996).

10. E. Węcławowicz-Gyurkovich, Postmodernizm w architekturze, [w:] Encyklopedia Kultury Polskiej $\mathrm{XX}$ wieku, od Awangardy do Postmodernizmu, p. 472 (Instytut Kultury, Warszawa, 1996).

11. J. Gil-Mastalerczyk, O przemianach architektury sakralnej Archidiecezji Krakowskiej w latach 19452000, doctoral dissertation under the direction of Dr. hab. Eng. architect Andrzej Białkiewicz, prof. PK, (Kraków, 2013).

12. T. P. Szafer, Sacrum Wadowickie, [w:] Udział pracowników Politechniki Krakowskiej w życiu Kościoła katolickiego za pontyfikatu Jana Pawła II, Flaga K., Paluch M., Pawlicki B.M. (red.), p. 157162 (Kraków, 1998).

13. H. Rogall, Ekonomia zrównoważonego rozwoju. Teoria i praktyka, p. 44 (Wyd. Zysk i S-ka, Poznań 2010).

14. G. Sznajder-Skalska, Projektowanie zrównoważone - zblizenie do realizacji [w:] Czasopismo Techniczne Architektura"/ Technical Transactions Architecture, Issue 3-A/2007, p. 257-265 (Wyd. Politechnika Krakowska, Kraków 2007).

15. S. Wehle-Strzelecka, Close-to nature housing austrian examples/ Architektura mieszkaniowa otwarta na przyrode - przykłady austriackie [w:] Czasopismo Techniczne Architektura/ Technical Transactions Architecture, Issue 3-A (3) Year 2014 (111)/ Z. 3-A(3) Rok 2014 (111), p. 147-160 (Wyd. Politechnika Krakowska, Kraków, 2014). 